\title{
The effective presentation of inquiry-based classroom experiments using teaching strategies that employ video and demonstration methods
}

\author{
Songul Sever, Ayse Oguz-Unver \\ Mugla Sitki Kocman University, Turkey
}

Kemal Yurumezoglu

Dokuz Eylul University, Turkey

\begin{abstract}
This study was conducted in the light of the philosophical framework of inquiry-based science education. The research involved the presentation of experiments on basic science concepts that have been tested for validity through inquiry-based processes. The experiments were formulated firstly to determine what differences there would be in student academic achievement and in their attitudes toward the school subject of Science and Technology when the experiments were introduced by demonstration or in a video. Another purpose of the study was to create technology-supported teaching materials to enrich the learning environment. The participants in the research were second-year preservice teachers $(N=149)$ who were students in classroom teaching. The study was of a quasi-experimental design and made use of a pretest, post-test and permanency test with a control group. The results then being merged with the observation notes of the researchers. The study set forth the strong and weak aspects of both teaching strategies and concluded that using both methods to complement each other would be effective in teaching and would also constitute an alternative to the teaching materials and strategies used in schools with scarce resources.
\end{abstract}

\section{Introduction}

Cell phones, computers, televisions and other devices are an inseparable part of our daily lives. Individuals are overpowered by all of these devices on a daily basis but still demand the right to benefit from technology in their formal educational processes as well. As a result, technology has inevitably entered the teaching environment. The most important prerequisites for living in today's information society are critical thinking and inquiry skills, the capability to access reliable information, and the capacity to use these assets in ordinary problem-solving and decision-making processes. The integrated structure and complexities of knowledge and technology bring inquiry into the forefront of information access processes and the teaching environment. Inquiry-based science education is a teaching strategy that is in harmony with constructivist learning theory and as such, is a practice that ensures students' interaction with surrounding objects and phenomena, and allows them the opportunity to benefit from technology. It is only when technology-supported teaching strategies are reinforced with inquiry-based science education that a more solid and meaningful integration of the individual's daily life and the learning experience in a teaching atmosphere can be achieved.

\section{Developing teaching materials by using videos in the teaching environment}

With the start of World War II, the use of audio-visual equipment for educational purposes declined while the practice of relying on this equipment showed an increase in the military and in industry (Reiser, Tabak, Sandoval, Smith, Steinmuller, \& Leone, 2001). When the U.S. began to use audio-visual apparatus to its advantage during the war, this equipment caught the attention of educators in classrooms and also stimulated interest in researching the effects this equipment had on learning (e.g., Lumsdaine, 1963). Subsequently, television was first to be introduced to schools and with technological advances, the use of videos and computers became more widespread, this in turn leading to more research on how these devices affect student achievement.

Video technology, as an offshoot of TV technology, found an important niche in the teaching environment because of the possibilities it offers with the audio-visual stimulation it provides. Inconvenient broadcasting times and the lack of control over presentations have made the use of 
television in classrooms problematic whereas video showings have offered advantages in this respect. Video materials support classroom teaching, assist in individual learning and are also helpful in distance education. This study has attempted to scan the literature to determine the different teaching applications of video; the studies accessed were grouped under five themes (see Table 1).

Table 1

Summary of previous studies on video teaching

\begin{tabular}{ll}
\hline Research themes & Reference \\
\hline Studies related to the use of video in the classroom & Akgün, 2005; Çakır, 2006; Dunlap, 1980; Felton, \\
teaching environment & Keesee, Mattox, McCloskey, \& Medley, 2001; \\
& Foskey, 1982; Geban, Ertepinar, Y1lmaz, Altın, \& \\
& Şahbaz, 1994; Koleza \& Pappas, 2006; Mandeng, \\
& 1978; Mayo, Sharma, \& Muller, 2009; Rüzgar,
\end{tabular}
2005

Studies related to the use of video for individual D'Ateno, Mangiapanello, \& Taylor, 2003; learning in the school environment Halisküçük \& Çiftçi-Tekinarslan, 2007; Graetz, Mastropieri, \& Scruggs, 2006; Görgen, 2005; Gürses, Bayrak, Yalçın, Açıkyıldız, \& Doğar, 2005; MacDonald, Clark, Garrigan, \& Vangala, 2005; Maione \& Mirenda, 2006; Mohammad, 1980; Şen, 2009; Teker, 1990.

Studies on the use of video in distance education Bell, Cockburn, McKenzie, \& Vargo, 2001; Üçkardeş, Şahin, Efe \& Küçükönder, 2004; Savaş \& Arıc1, 2009.

Studies on interactive video applications Bell, Cockburn, McKenzie, \& Vargo, 2001; Bennet \& Maniar, 2007; Brotherton \& Abowd, 2004; Chiu, Lee, \& Yang, 2006; Day \& Foley, 2006; Escalada, Grabhorn, \& Zollman, 1996; Escalada \& Zollman, 1997; Şimşek, 1993; Zupancic \& Horz 2002.

Studies on teaching materials developed with the Kert \& Tekdal, 2008; Klee \& Bayrhuber 2002; use of multimedia (the use of at least two of the Numanoğlu, 1992; Numanoğlu, 1993; Özdener, mediums of graphics, animation, sound and music, 2005; Taşç1 \& Soran, 2008; Yaman, 2005. video)

These studies, which were developed to enrich the environment of teaching information and communication technologies, increase student motivation, and in connection with this, enhance academic achievement. Such efforts started in the 1950's with television, and continued with the use of video in classrooms. It can be seen in the studies that there are two areas of benefit that video provides in teaching environments. One of these relates to the way in which video stimulates concentration and motivation in students throughout the teaching process (e.g., Roskos-Ewoldsen \& Roskos-Ewoldsen 2001; Hazen, Kelly, \& Sramek, 2002; Hoover, 2006; Oishi, 2007). The second area of benefit has to do with the power of video in helping students conceptualize and internalize difficult and abstract topics (e.g., Verran, 1992; Harwood \& McMahon 1997; Liedtka 2001; Herron, Dubreil, Corrie, \& Cole, 2002; Green, Voegeli, Harrison, Phillips, Knowles, Weaver, \& Shephard, 2003; Brunvand \& Fishman, 2007; De Leng, Dolmans, Van de Wiel, Muijtjens, \& Van Der Vleuten, 2007; Palmer, 2007; White, 2007).

The fact that technology in and of itself does not have an adequate impact on learning has led to the development of various teaching materials and strategies. The characteristics of such materials and the effects of teaching strategies on individual learning have formed the basis for many studies. Similarly, the present study as well has been designed to examine the impact of technology-supported teaching materials and different presentation strategies on learning and has suggested a means of developing supplementary teaching materials to support broad-based science education.

The study was conducted from the perspective of identifying the needs of today's teaching programs. It reviews the effects on the academic achievement of pre-service teachers and on their attitudes toward Science and Technology of presenting experiments using video and demonstration strategies constructed within the context of a philosophy of inquiry-based science education. In this process, teaching the 
concepts of sight, reflection, deflection, absorption, shadow, half-shadow, full shadow through activities related to the interaction between light and matter, the concepts of the states of matter and density through activities related to global warming, the concepts of Archimedes' principle and buoyancy through activities related to the buoyant force of fluids, the concepts of conductivity, insulation through activities related to electricity, the concept of the phenomenon of the seasons through activities related to photosynthesis and the concept of chromatography related to activities related to the separation of mixtures in chemistry, have been targeted. Answers were sought to the following questions during the course of the study and at its conclusion:

1. How does teaching basic concepts and topics of science by making use of a strategy of presenting experiments with a video or by active demonstration affect learning and concept retention?

2. How does presenting experiments using the strategy of video or demonstration affect student attitudes toward Science and Technology?

3. What are the advantages and disadvantages of presenting experiments using the strategy of video or demonstration?

\section{Materials and method}

\section{Research model}

In keeping with the goals of the study, a quasi-experimental design with a control group and pretest, posttest and permanency tests were employed.

\section{Participants in the research}

The participants in the research were second-year students in the School of Education, Department of Classroom Teaching of a Western Anatolian University during the 2009-2010 academic year; the total number of students in Tier I and II was 149. The pre-service classroom teachers in Tiers I and II were attending classes in two groups, A and B, occupying a total of four classes. Students randomly chosen from Tier I-A and Tier II-A classes comprised the control group, while students from Tier I-B and Tier IIB classes made up the study group.

\section{Data collection tools}

A Science and Technology Attitude Test (pretest, post-test), an academic achievement test (pretest, posttest and permanency test) and the researchers' observation notes taken during the teaching process were used in the research as data collection tools.

Science and technology attitude testIn order to determine and compare students' attitudes toward Science and Technology before and after the implementation of the study, an attitude test was drawn up on the basis of similar tests found in the field literature (Demirbaş \& Yağbasan, 2006; Karacak-Deren, 2008; Nuhoğlu, 2008;). The attitude scale contained 30 positive and 14 negative, a total of 44 propositions. The expected answers in this 5-item Likert type of scale were I definitely agree, I agree, I'm undecided, I don't agree and I definitely don't agree. The students were asked to pick the appropriate answer. The Cronbach Alpha coefficient for the reliability of the test was found to be 0.991 .

\section{Academic achievement test}

The academic achievement test was developed by the researchers on the basis of the results of experiments tried and tested previously by other researchers. The academic achievement test was composed of a total of 35 questions (see Appendix). The test consisted of statements designed to receive a response of True, False or I don't know and the student was asked to mark the appropriate response and furnish a reason for that response. The students' responses were evaluated according to their choice of reply and the accuracy and consistency of the reasons they offered for these responses. The Cronbach Alpha coefficient for the reliability of the test was found to be 0.735 . 


\section{Researcher observation notes}

The researchers took down observation notes during the 6-weeks study in order to be able to review the students' skills in finding associations between the experiments and the concepts they learned. The notes were also used to assess the advantages and disadvantages of the teaching strategies that were being used during the study. The observations were noted around the framework of the questions, (1) How successful were the students in being able to form associations between the experiments? (2) What were the advantages and disadvantages of introducing these experiments with a video? and (3) comparatively, what were the advantages and disadvantages of demonstrating the experiments?

\section{The experiments}

The teaching process in the study was comprised of four main topics and a total of six experiments related to these topics. The topics and experiments were the following:

1. Experiments on the interaction of light and matter

a. Is Space Dark Or Light? (Yurumezoglu \& Oguz, 2009a),

b. Teaching Basic Optical Concepts: Can Shadows Be Coloured? (Yurumezoglu, 2009),

2. Photosynthesis:

a. Winter Comes To Our Campus (Oguz-Unver, Yurumezoglu, \& Sever, 2011),

3. Electricity:

a. Teaching Basic Concepts Of Electricity With A Test-Light Screwdriver (Fischer \& Gluck, 2008; Oflaz \& Yürümezoğlu, 2009),

4. The forms of matter and the buoyancy of fluids

a. Will Global Warming Cause A Rise In Sea Levels? A simple activity about the states of water (Oguz, 2009),

b. An experiment on archimedes' principle clarifies the concept of buoyancy (Oguz \& Yurumezoglu, 2008; Yurumezoglu \& Oguz, 2009b)

The common characteristic of the experiments was firstly that all of them were developed by the researchers on the basis of unique practical testing in the classroom. In addition, their implementation could be carried out with simple materials, they were related to events and phenomena in nature that could be easily observed, they were suitable for inquiry-based learning, and finally, they had been designed with a focus on the scientific process and interdisciplinary associations. The videos used in the activities can be seen on the webpage http://www.bilimdukkani.com/index.php/using-joomla/parameters.

\section{Presentation of the experiments and collection of data}

The students participating in the study were volunteers, of which 78 made up the control group and 71 the study group. While the experiments were presented to the control group by demonstration, the study group watched the experiments on video. The difference between the control and study groups therefore was the form of presentation of the experiment - the experiment was introduced to the classroom as a live demonstration or as a video. The experiments were designed to stimulate hypothetical-deductive reasoning and inquiry. Over the course of the presentation of the experiments to the two groups, discussions were conducted on critical issues the researchers thought worthy of bringing up and also on topics about which students asked questions.

The videos of the experiments presented in the study were created by the researchers themselves. The video tapes were cut, edited, spliced and prepared for presentation using the Windows Movie Maker program.

In teaching the control group, the experiments were demonstrated as part of an inquiry-based process which means even though the students were only able to observe the experiment while the instructor was doing it; the students' minds were stimulated by instructor's questions. In other words students were always inquiring for the next step to check their hypothesis. In the study group, the experiments were presented through the medium of a video, which had been prepared by the researchers on the basis of the feedback that had been gained from the interaction with the control group in the teaching process. Thus, the only difference between the two approaches was how the experiment was presented. In both cases, the students were able to ask questions after or during experiments. 


\section{Results}

\section{Quantitative results on the effect of the experiments on attitudes about science and technology}

The mean scores, standard deviation values of the pre-service teachers on the pretest and post-test applications implemented to determine their attitudes towards Science and Technology are given in Table 2.

Table 2

Mean and standard deviation values on the science and technology attitude scale

\begin{tabular}{lcccccc}
\hline & \multicolumn{3}{c}{ Pretest } & \multicolumn{3}{c}{ Post-test } \\
\cline { 2 - 7 } Group & $N$ & $\bar{X}$ & $S$ & $N$ & $\bar{X}$ & $S$ \\
\cline { 2 - 7 } Demonstration & 78 & 3.8141 & 0.71 & 78 & 3.2622 & 1.56 \\
Video & 71 & 3.7190 & 0.73 & 71 & 3.7733 & 0.37 \\
\hline
\end{tabular}

In this study, which implemented two different teaching strategies, the two-way ANOVA was used to determine whether there was a significant difference between the attitudes of the pre-service teachers toward Science and Technology in the pre- and post-tests. In the repeated measurements in the groups where experiments were introduced to students by demonstration or with a video against a background of a philosophy of inquiry-based science education, it was found that the effect of the two factors on the attitudes of the students toward Science and Technology was not statistically significant $\left[F_{(1,147)}=7.631\right.$, $p>0.001]$.

\section{Quantitative results on the effects of the experiments on the students' academic achievement}

The mean scores, standard deviation values on the pretest, post-test and permanency test scales implemented to determine the academic achievement of the pre-service teachers are given in Table 3.

Table 3.

Mean and standard deviation values on the academic achievement scale

\begin{tabular}{lccccccccc}
\hline \multirow{2}{*}{ Group } & \multicolumn{3}{c}{ Pretest } & \multicolumn{3}{c}{ Post-test } & \multicolumn{3}{c}{ Retention test } \\
\cline { 2 - 10 } & $N$ & $\bar{X}$ & $S$ & $N$ & $\bar{X}$ & $S$ & $N$ & $\bar{X}$ & $S$ \\
\cline { 2 - 9 } $\begin{array}{l}\text { Demonstration } \\
\text { (Control) }\end{array}$ & 78 & 43.19 & 13.60 & 78 & 83.15 & 7.51 & 78 & 64.98 & 35.13 \\
$\begin{array}{l}\text { Video } \\
\text { (Study) }\end{array}$ & 71 & 41.17 & 13.38 & 71 & 86.04 & 12.77 & 71 & 68.61 & 29.41 \\
\hline
\end{tabular}

In this study, where two different strategies of teaching were implemented, the two-way ANOVA (2x3) was used to determine whether there were significant differences in the changes in students' academic achievement before the presentations, after the presentations and at the end of a determined time. Accordingly, it was observed that there was no significant difference between the academic achievement of the control group, who saw the demonstration and that of the study group, who had watched the experiment on video $\left[F_{(1,147)}=0.537, p>0.001\right]$.

It was also seen that there were no significant differences between the achievement scores on the pretest, post-test and permanency tests of the study and control groups, both of which had been presented the experiments with a different approach $\left[F_{(2,294)}=0.795, p>0.001\right]$. It can be concluded therefore that presenting an inquiry-based experiment either by demonstration or with a video does not have a significant impact on students' academic achievement. In other words, neither one of the teaching 
strategies used was superior to the other in this sense. It was however found that repeated measurements of the pretest, post-test and permanency test in both the study and control groups within the groups themselves revealed significant differences in academic achievement $\left[F_{(2,294)}=153.007, p<0.001\right]$. The differences showed that in both groups, the results of the post-test indicated a higher academic achievement compared to the pretest, but a decreased achievement in the permanency test as compared to the post-test (see Figure 1).

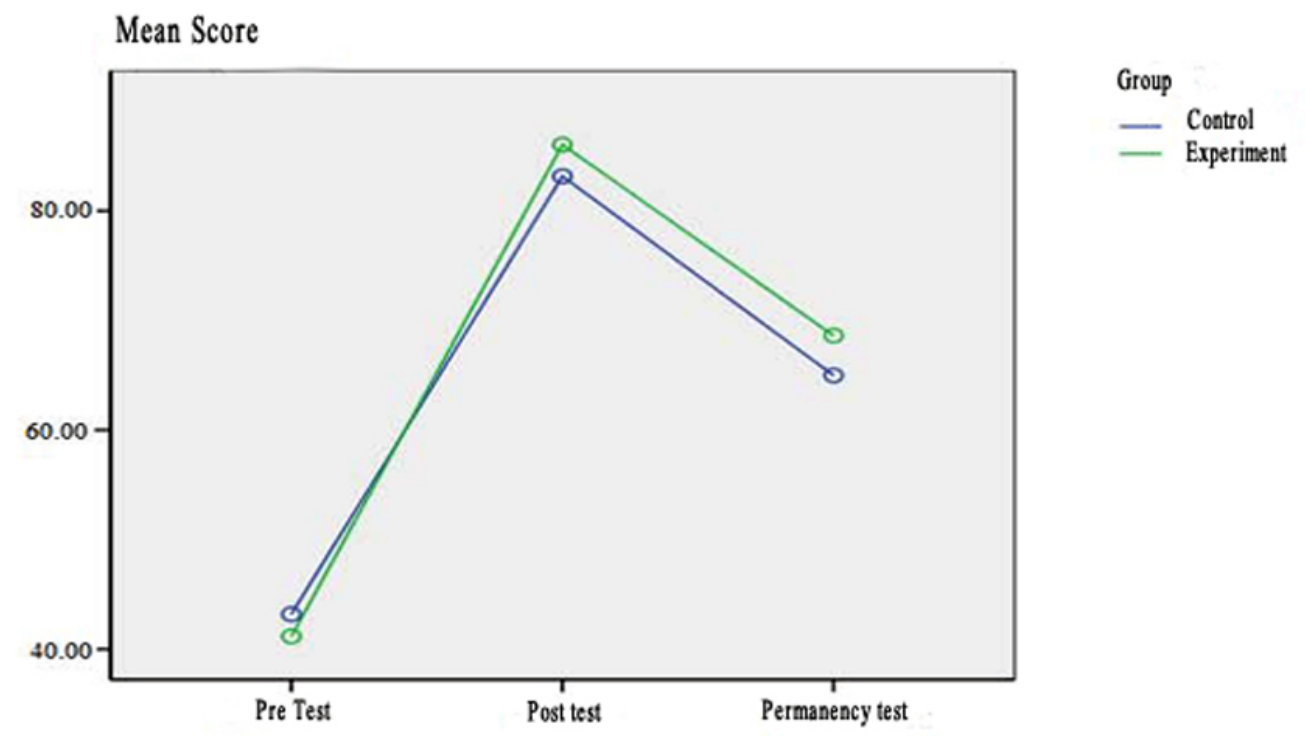

Figure 1. The change in the pretest/post-test/retention test scores of the groups.

\section{A qualitative comparison of the academic achievement of the students in the study who watched the experiment by as a demonstration or on video}

This section will be concerned with reporting the researchers' observations and interpretations of the comparative advantages and disadvantages of a teaching strategy of presenting an experiment as a demonstration or on video. The ability of the students to form associations between various experiments will also be examined. The observations are based on three predefined questions and were collected over a period of 6 weeks, a different experiment being presented each week.

In the observations made on whether the students were able to form an association between experiments, it was seen that they were able to associate the two experiments concerned with light and matter (Is Space Dark Or Light? and Teaching Basic Optical Concepts: Can Shadows Be Coloured?). On the other hand, the students had pronounced difficulty in connecting the experiment Winter Comes To Our Campus with the topic they had learned about in the previous two experiments. This was because in the Winter Comes to our Campus experiment, they had concentrated on the field of biology when learning about photosynthesis and did not consider the interaction of light and matter in terms of physics. On the other hand, the students were able to remember and transfer the knowledge they gained about Archimedes' principle in the Buoyancy experiment to the Global Warming experiment. It was striking to note that the students were able not only to make the connection between experiments but also to merge this knowledge with their observations from everyday life. For example, in the Global Warming experiment, the students were able to consolidate and share their knowledge that water freezing from top to bottom was an exception when they remembered that olive oil froze from bottom to top in their refrigerators at home. In the Buoyancy experiment, when asked the question, "What can we do to make a sunken orange float again?" it was seen that the students were able to connect their observations from everyday life with this phenomenon by saying, "My mother puts an egg into the pickle juice when she's making pickles and then she adds salt until the egg floats." 
The interpretations of the observations related to how the advantages and disadvantages of the video and demonstration teaching strategies would compare with each other are provided below. In the group where the experiments were presented as demonstrations, the experiments were performed with the available laboratory materials in line with the needs of the students and were carried out with different variables. In the group presented with the video, however, this was not possible and because of this, the inability of students to join in with alternative applications and experiments was a disadvantage.

Although no significant difference was found between student attitudes toward Science and Technology in the quantitative section of the study, in general, in the group presented with a video, it was observed that student motivation with regard to the class was higher as was also the interaction between the guiding instructor and the students. This was because the instructor, instead of performing the experiment, had more time to engage the students in discussions. It was also due to the video's own effectiveness, a result of its being prepared by one of the regular instructors teaching the class. At the same time, because of the shortness of the video - taking up a maximum 15 minutes - there was more of a chance for studentinstructor interaction to be managed effectively, attention could be drawn to integrated topics, and more discussions could take place. From these aspects, the active demonstration of an experiment is more advantageous.

Comparing the video and demonstration forms of the experiment presentations from the perspective of the guiding instructor, it was seen that the instructor in the study group saved time since there was no active implementation of the experiment. Also, control of the class was more easily achieved because of the opportunity to make constant eye contact with the students. When observed from a qualitative viewpoint, both the video and the demonstration method of presenting experiments have different advantages over each other. In experiments presented with a video, it may be beneficial to support the presentation with a demonstration in so far as available materials in the laboratory allow. On the other hand, there are situations where demonstrations of experiments do not achieve their full purpose. It would be useful in such circumstances to use audio-visual teaching materials in order to increase student's academic performance.

\section{Discussion}

This section seeks to discuss the results obtained from the study and compare these with the results of previous studies. In the first part of the discussion, the effect of inquiry-based demonstrations of experiments and video presentations on students' academic achievement will be examined. The present study has shown that supporting inquiry-based teaching with video presentations increases student achievement and ensures learning permanency and the improvement of mental process skills, but that the method has both advantages and disadvantages. The advantages of the inquiry-based video presentation teaching strategy are as described below.

- Videos are an effective teaching tool in crowded classrooms.

- In laboratories with scant materials, videos constitute an alternative teaching material.

- They increase instructor-student interaction.

- Videos allow the presentation of long experiments in a limited time frame.

- Audio-visual stimulants help to keep student motivation high in the classroom.

- Developing teaching materials beforehand is convenient for teachers in their classroom preparation. Instructors can watch the targeted experiment on a video before class and then revise the presentation to meet the needs of the particular group of students, making it more functional in a new form. The results of studies that have focused on the use of inquiry-based teaching materials and how they can be useful to students in terms of providing easy comprehension and to teachers as a guideline for teaching, are consistent with the outcome of the present study (e.g., Edelson, Gordin, \& Pea, 1999; Kumpulainen, Vasama, \& Kangassalo, 2003).

- The use of videos in the teaching process facilitates time management. Sometimes when experiments performed in the classroom do not produce expected results, teachers are challenged in trying to fit in a repeat of the experiment in the limited amount of class time. The teaching materials developed in the study make it possible for students to make an immediate observation in cases where experiments have not produced the expected result. It is for this reason that it 
would facilitate the work of instructors if similar teaching materials could be made available in Science and Technology laboratories.

- $\quad$-The use of videos in the classroom also provides students with a resource for professional development. In the study, students were asked to present experiments on various topics at the end of the initial application. It was observed that some of the students' presentations were very similar to the manner of the presentation made by the instructor, down to the seating of the students in the classroom. It was thus seen in the study that the use of a video in the classroom served not only to increase students' academic achievement but also constituted a model for professional development. In studies where videos have been used as model teaching materials (Foskey, 1982; D'Ateno, Mangiapanello, \& Taylor, 2003; Stoelb, 2004; MacDonald et al., 2005; Graetz et al., 2006; Maione \& Mirenda, 2006), it has been shown that this tool has increased psychomotor skills and academic achievements in individuals with different mental and physical characteristics; this is a result that is paralleled in the present study. Besides being used as a model material, as in the present study, videos can be used in the micro-teaching process, where this method has been seen to have a positive influence on the development of pre-service teachers (e.g., Gürses et al., 2005; Görgen, 2005; Şen, 2009).

The inquiry-based teaching strategy of using videos in this study was observed to have two disadvantages. One of these disadvantages stemmed from the discomfort students felt in having to watch the video in the dark for a long time; the second disadvantage was that students had no time to examine the experimental materials and try the experiments themselves.

The second part of the discussion will review the effect of the inquiry-based demonstrations and the video version of the experiments on the attitudes of the students toward their Science and Technology class. It was found in the study that when demonstrations and video presentations prepared in the light of the philosophy of inquiry-based education were compared, as seen in Table 2, the approach of the group watching the video presentation was more positive. As can be seen in Table 2, a quantitative analysis revealed that the difference in attitude between the study and control group was not significant. According to the researchers' observations, the students in the group watching the video were found to participate more and display a higher degree of motivation. The results of this study are consistent with those of the studies of Benney (2001), Roskos-Ewoldsen \& Roskos-Ewoldsen (2001), Hazenet al. (2002), Hoover (2006) and Oishi (2007).

Over the course of the implementation of the present study, it was observed that inquiry-based teaching encouraged students to develop a positive attitude toward their subjects. In fact, the students frequently expressed their satisfaction with the type of inquiry-based teaching process that they encountered in the study. This process consisted of a research question which inspired students to think and share their ideas throughout the course of the experiments, subsequently stimulating them to actively interpret and apply what they learned. The students voiced their wish that this method be implemented in their other courses and stated that they had already started to look at the world of nature with a different perspective. The qualitative research results, which showed that teaching using an inquiry-based teaching philosophy had a positive effect on the attitudes of students towards the class, are consistent with the findings of Kilınç (2007).

The results and framework of this study are restricted to the number of participants included in the research and their characteristics, the number and content of the experiments performed, the implementation time of the research, and also by the limitations of the data collection instruments. Expanding the samples and repeating the procedures in similar studies with groups in different branches, making changes in the number of experiments and in their content will make possible more comprehensive and reliable results.

\section{Conclusion}

This study has examined, in the light of the philosophy of inquiry-based science education, how presenting experiments as a demonstration or in the form of a video affect the attitudes of students toward their Science and Technology class and their academic achievement. To conclude, it has been set forth that the presentation of experiments with inquiry-based demonstrations or in the form of a video has a positive influence on students' attitudes toward science and technology and contributes to increasing their 
academic achievement. Moreover, the results of this study and of the research that has been reviewed here point to the importance and need for technology-supported teaching strategies in achieving educational productivity.

Using inquiry-based supporting material and presenting these by employing different strategies in this study not only enriched the learning environment but also provided students with a better configuration of the scientific knowledge in their minds through inquiry. Since the experimental methods and the inquiry conducted in this study were consistent with the nature of science itself, students were able to develop an attitude and awareness that helped them to understand science and look positively at natural phenomena. At the same time, because the experiments were chosen from everyday life experience, the students were able to participate actively in the thought and inquiry process and the entertaining content stimulated their motivation. Additionally, presenting experimental activities with different strategies that can produce the same results can be an advantage in schools that be may be at a disadvantage in terms of having access to teaching tools and equipment. There is also advantage in increasing the alternatives in terms of teaching tools and providing teachers with more effective strategies and methods to choose from in the different stages of their professional development. All of this will not only provide incentive for inquiry-based teaching but will also expand upon the framework of conducting effective education and instruction.

\section{Further implication}

The presentation of different strategies for presenting experiments may also be examined in terms of the development of students' scientific processing, their critical and creative thinking, and their problemsolving skills. A similar study may test these findings in different student groups and in larger samples, examining the usability of materials that have been developed in different teaching environments. Numerous experiments on different concepts and subjects may be brought together to create a video that would be effective in presenting these experiments, with a teaching set perhaps being put together for the use of both teachers and students. Finally, the present study showed that supporting inquiry-based teaching with video and demonstration approaches improving the students learning. However, in some cases the method has both advantages and disadvantages. Therefore, more studies may need to study how the approaches could complement each other.

\section{Acknowledgements}

This research has funded from Mugla Sitki Kocman University Scientific Research Projects Programme under the Grant Agreement No. BAP-09/37.

\section{References}

Akgün, Ş. (2005). Fen bilgisi öğretimi. Pegem-A Yayıncılık.

Bell, T., Cockburn, A., McKenzie, B., \& Vargo, J. (2001). Flexible delivery damaging to learning? Lessons from the Canterbury Digital Lectures Project. Proceedings of the World Conference on Educational Multimedia, Hypermedia and Telecommunications, June 25-30, Finland. 1(1), 117-122.

Bennett, E., \& Maniar, N. (2007). Are videoed lectures an effective teaching tool. Retrieved from http://podcastingforpp.pbworks.com/f/Bennett\%20plymouth.pdf.

Benney, A. (2001). Creating an active learning environment using digital video what I did and how I did it. In World Conference on Educational Multimedia, Hypermedia and Telecommunications (Vol. 1, pp. 133-138).

Brotherton, J. A., \& Abowd, G. D. (2004). Lessons learned from eClass: Assessing automated capture and access in the classroom. ACM Transactions on Computer-Human Interaction (TOCHI), 11(2), 121-155. 
Brunvand, S., \& Fishman, B. (2006). Investigating the impact of the availability of scaffolds on preservice teacher noticing and learning from video. Journal of Educational Technology Systems, 35(2), 151-174.

Chiu, C. F., Lee, G. C., \& Yang, J. H. (2006). A comparative study of post-class lecture viewing. In Proceedings of the 5th IASTED international conference on Web-based education (pp. 126-130). Puerto Vallarta, Mexico.

Çakır, İ. (2006). The use of video as an audio-visual material in foreign language teaching classroom. Turkish Online Journal of Educational Technology, 5(4), 67-72.

D'Ateno, P., Mangiapanello, K., \& Taylor, B. A. (2003). Using video modeling to teach complex play sequences to a preschooler with autism. Journal of Positive Behavior Interventions, 5(1), 5-11.

Day, J., \& Foley, J. (2006, April). Evaluating web lectures: A case study from HCI. Paper presented at the conference on human factors in computing systems, Montreal, Canada. Retrieved from http://portal.acm.org/citation.cfm?id=1125493.

De Leng, B. A., Dolmans, D. H., Van de Wiel, M. W., Muijtjens, A. M. M., \& Van Der Vleuten, C. P. (2007). How video cases should be used as authentic stimuli in problem-based medical education. Medical Education, 41(2), 181-188.

Demirbaş, M., \& Yağbasan, R. (2006). Fen bilgisi öğretiminde bilimsel tutumların işlevsel önemi ve bilimsel tutum ölçeğinin Türkçeye uyarlanma çalışması. Uludă̆ Üniversitesi Ĕgitim Fakültesi Dergisi, 19(2), 271-299.

Dunlap, J. B. (1980). A comparative study of cognitive and affective changes in business English students in associate degree programs using printed or videotaped review materials (Doctoral dissertation, University of Akron, College of Education). Dissertation Abstracts International: The Humanities and Social Sciences, 45(9), 5899.

Edelson, D. C., Gordin, D. N., \& Pea, R. D. (1999). Addressing the challenges of inquiry-based learning through technology and curriculum design. Journal of the Learning Sciences, 8(3-4), 391-450.

Escalada, L.T., Grabhorn, R., \& Zollman. D.A. (1996). Applications of interactive digital video in a physics classroom. Journal of Educational Multimedia and Hypermedia, 5(1), 73-97.

Escalada, L. T., \& Zollman, D.A. (1997). An investigation on the effects of using interactive digital video in a physics classroom on student learning and attitudes. Journal of Research in Science Teaching, $34(5), 467-489$.

Felton, L. A., Keesee, K., Mattox, R., McCloskey, R., \& Medley, G. (2001). Comparison of video instruction and conventional learning methods on students' understanding of tablet manufacturing. American Journal of Pharmaceutical Education, 65(1), 53-55.

Fischer, S., \& Gluck, P. (2008). Tool teaches electricity concepts. Physics Education, 43(3), 254.

Foskey, H. (1982). The effectiveness of video-tape presentations on teaching precision linear instrument measurement skills utilizing a micrometer relative to the cognitive and psychomotor achievement of male and female college students with varying abilities (Unpublished doctoral dissertation, Temple University).

Geban, Ö., Ertepınar, H., Yılmaz, G., Altın, A., \& Şahbaz, F. (1994). Bilgisayar destekli eğitimin öğrencilerin fen bilgisi başarılarına ve fen bilgisi ilgilerine etkisi. Ulusal Fen Bilimleri Eğitimi Sempozyumu: Bildiri Özetleri Kitabı, (pp. 1-2). İzmir: Dokuz Eylül Üniversitesi.

Görgen, İ. (2005). Mikroöğretim uygulamasının öğretmen adaylarının sınıfta ders anlatımına ilişkin görüşleri üzerine etkisi. Hacettepe Üniversitesi Eğitim Fakültesi Dergisi, 24, 56-63. 
Graetz, J. E., Mastropieri, M. A., \& Scruggs, T. E. (2006). Show time using video self-modeling to decrease inappropriate behavior. Teaching exceptional children, 38(5), 43-48.

Green, S. M., Voegeli, D., Harrison, M., Phillips, J., Knowles, J., Weaver, M., \& Shephard, K. (2003). Evaluating the use of streaming video to support student learning in a first-year life sciences course for student nurses. Nurse Education Today, 23(4), 255-261.

Gürses, A., Bayrak, R., Yalçın, M., Açıkyıldız M., \& Doğar, Ç. (2005). Öğretmenlik uygulamalarında mikroöğretim yönteminin etkililiğinin incelenmesi. Kastamonu Eğitim Fakültesi Dergisi, 13(1), 1-10.

Halisküçük, E.S., \& Çiftçi-Tekinarslan, İ. (2007). Zihinsel yetersizliği olan öğrencilere makarna pişirme becerisinin öğretiminde videoyla model olmanin etkililiği. AIB̈̈̈, Egitim Fakültesi Dergisi, 7(2), 112 128.

Harwood, W. S., \& McMahon, M. M. (1997). Effects of integrated video media on student achievement and attitudes in high school chemistry. Journal of Research in Science Teaching, 34(6), 617-631.

Hazen, C., Kelly, D., \& Sramek, H. (2002). Video as a tool to change attitudes on teaching science and mathematics. In Pathways to Change: An International Conference on Transforming Math and Science Education in the K16 Continuum Proceedings. Retrieved from

http://www.google.com/search?hl=en\&q=Video+as+a+Tool+to+Change+Attitudes+on+Teaching + Sci ence+and+Mathematics

Herron, C., Dubreil, B., Corrie, C., \& Cole, S. P. (2002). A classroom investigation: can video improve intermediate-level French language students' ability to learn about a foreign culture? The Modern Language Journal, 86(1), 36-53.

Hoover, D. S. (2006). Popular culture in the classroom: Using audio and video clips to enhance survey classes. The History Teacher, 39(4), 467-478.

Karacak-Deren, Ş. (2008). İlköğretim 8. sınıf genetik ünitesinin 5e modeline göre tasarlanan multimedya destekli ögretimin öğrencilerin erişi ve tutumlarına etkisi. (Unpublished master's thesis). Muğla: Muğla Üniversitesi, Fen Bilimleri Enstitüsü.

Kert, S.B., \& Tekdal, M. (2008). Alanyazındaki tasarım ilkelerine uygun olarak geliştirilmiş çokluortam ders yazılımının lise düzeyi fizik öğretiminde akademik başarıya ve kalıcılığa etkisi. Pamukkale Üniversitesi Eğitim Fakültesi Dergisi, 23, 120-131.

Kilınç, A. (2007). The opinions of Turkish high school pupils on inquiry based laboratory activities. The Turkish Online Journal of Educational Technology, 6(4), 56-71.

Klee, R., \& Bayrhuber, H. (2002). Multimedia im ökologieunterricht: lernprozesse und programmgestaltung. In Lehr - und Lernforschung in der Biologiedidaktik (Vol. 1, pp. 187-198). Innsbruck: Studienverlag.

Koleza, E., \& Pappas, J. (2008). The effect of motion analysis activities in a video-based laboratory in students' understanding of position, velocity and frames of reference. International Journal of Mathematical Education in Science and Technology, 39(6), 701-723.

Kumpulainen, K., Vasama, S., \& Kangassalo, M. (2003). The intertextuality of children's explanations in a technology-enriched early years science classroom. International Journal of Educational Research, 39(8), 793-805.

Liedtka, J. (2001). The promise and peril of video cases: Reflections on their creation and use. Journal of Management Education, 25(4), 409-424. 
Lumsdaine, A. A. (1963). Instruments and media of instruction. In N. L. Gage (Ed.), Handbook of research on teaching (pp. 583-682) Chicago: Rand McNally.

MacDonald, R., Clark, M., Garrigan, E., \& Vangala, M. (2005). Using video modeling to teach pretend play to children with autism. Behavioral Interventions, 20(4), 225-238.

Maione, L., \& Mirenda, P. (2006). Effects of video modeling and video feedback on peer-directed social language skills of a child with autism. Journal of Positive Behavior Interventions, 8(2), 106-118.

Mandeng, S. B. (1978). The 6:30 pm videotaped national news as an effective device for the teaching of world geography (Unpublished doctoral dissertation, University of Maine).

Mayo, A., Sharma, M. D., \& Muller, D. A. (2009). Qualitative differences between learning environments using videos in small groups and whole class discussions: A preliminary study in physics. Research in Science Education, 39(4), 477-493.

Mohamed, N. A. A. (1980). Evaluation of videotapes as a supplement in a college zoology course (Doctoral dissertation, Iowa State University of Science and Technology). Dissertation Abstracts International: The Humanities and Social Sciences, 41(6), 2540.

Nuhoğlu, H. (2008). İlköğretim fen ve teknoloji dersine yönelik bir tutum ölçeğinin geliştirilmesi. Ilköğretim Online, 7(3), 627-639.

Numanoğlu, M. (1992). Milli ĕgitim bakanlı̆̆ bilgisayar destekli ĕgitim projesi bilgisayar destekli ögretim ders yazılımlarında bulunması gereken eğitsel özellikler. (Unpublished master's thesis) Yayınlanmamış Yüksek Lisans Tezi. Ankara: Ankara Üniversitesi Sosyal Bilimler Enstitüsü.

Numanoğlu, M. (1993). Eğitimde yeni teknolojiler ve çoklu ortam. Ankara Üniversitesi Ĕgitim Bilimleri Fakültesi Dergisi, 26(1), 219-226.

Oflaz, Ö., \& Yürümezoğlu, K., (2009). Kontrol kalemi ile temel elektrik kavramlarını öğretmek. Ĕ̆itimde İyi Örnekler Konferansı, 18-19 Nisan, Sabancı Üniversitesi, İstanbul. (pp. 192-195).

Oguz, A. (2009). Will global warming cause a rise in sea level? A simple activity about the states of water. Science Activities: Classroom Projects and Curriculum Ideas, 46(1), 17-20.

Oguz, A., \& Yurumezoglu, K. (2008). Experiment clarifies buoyancy. Physics Education, 43(3), 247-248.

Oguz-Unver, A., Yurumezoglu, K., \& Sever, S. (2011). Teaching science using the language of nature: winter comes to our campus. International Electronic Journal of Environmental Education (IEJEE), $1(2), 141-149$.

Oishi, L. (2007). Did you just see that? Online video sites can jumpstart lessons. Technology and Learning, 27(6), 32.

Özdener, N. (2005). Deneysel öğretim yöntemlerinde benzetişim (simulation) kullanımı. The Turkish Online Journal of Educational Technology-TOJET, 4(4), 93-98.

Palmer, S. (2007). An evaluation of streaming digital video resources in on-and off-campus engineering management education. Computers \& Education, 49(2), 297-308.

Reiser, B. J., Tabak, I., Sandoval, W. A., Smith, B. K., Steinmuller, F., \& Leone, A. J. (2001). BGuILE: Strategic and conceptual scaffolds for scientific inquiry in biology classrooms. In S. M. Carver \& D. Klahr (Eds.), Cognition and instruction: Twenty-five years of progress (pp. 263-305) Mahwah, NJ: Erlbaum.

Roskos-Ewoldsen, D. R., \& Roskos-Ewoldsen, B. (2001). Using video clips to teach social psychology. Teaching of Psychology, 28(3), 212-15. 
Rüzgar, B. (2005). Bilginin eğitim teknolojilerinden yararlanarak eğitimde paylaşımı. The Turkish Online Journal of Educational Technology - TOJET, 4(3), 114-119.

Savaş, S., \& Arıcı, N. (2009). Web Tabanlı Uzaktan Eğitimde İki Farklı Öğretim Modelinin Öğrenci Başarısı Üzerindeki Etkilerinin İncelenmesi. 5. Uluslararası İleri Teknolojiler Sempozyumu (IATS'09), Karabük, Türkiye.

Stoelb, M. 2004. Teaching expressive labeling to children with autism via videotape modeling. University of Missouri, Columbia.

Şen, A. İ. (2009). Akran-mikro öğretimin öğretmen yetiştirmede programındaki etkisinin araştırılması. Eğitim ve Bilim, 34(151), 165-174.

Şimşek, N. (1993). Otomasyon teknolojisi: kendi kendine aktif öğrenme. Ankara Üniversitesi Ĕ̆itim Bilimleri Fakültesi Dergisi, 26(1), 215-218.

Taşcı, G., \& Soran, H. (2008). Hücre bölünmesi konusunda çoklu ortam uygulamalarının kavrama ve uygulama düzeyinde öğrenme başarısına etkisi. Hacettepe Üniversitesi Ĕ̆itim Fakültesi Dergisi, 34, 233-243.

Teker, N. (1991). Video ve eğitimde kullanılması. Ankara Üniversitesi Ĕ̈itim Bilimleri Fakültesi Dergisi, 24(2), 423-447.

Üçkardeş, F., Şahin, M., Efe, E., \& Küçükönder, H. (2004). Bilgi ve İletişim Teknolojilerine Dayalı Uzaktan Eğitim. Retrieved from http://4uzbk.sdu.edu.tr/4UZBK/POSTER/BGP/4UZBKP_064.pdf, $21 / 12 / 2010$

Verran, J. (1992). The use of video in transferable skills education for biology students I. Production of pilot videos. Journal of Further and Higher Education, 16(1), 96-102.

White, C. (2007). Students' perceived value of video in a multimedia language course. Educational Media International, 37(3): 167-175.

Yaman, M. (2005). Solunum zinciri konusunda simülasyonla desteklenmiş bir bilgisayar programının öğrenme ve ilgiye etkisi. Hacettepe Üniversitesi Ĕ̈itim Fakültesi Dergisi, 29, 222-228.

Yurumezoglu, K. (2009). An entertaining method of teaching concepts of linear light propagation, reflection and refraction using a simple optical mechanism. Physics Education, 44(2), 129-132.

Yurumezoglu, K., \& Oguz, A. (2009a). The darkness of space: A teaching strategy. Science Activities: Classroom Projects and Curriculum Ideas, 46(4), 15-17.

Yurumezoglu, K., \& Oguz, A. (2009b). Hipotez test sürecinde çocukların ve yetişkinliklerin bilimsel düşünme eğilimleri (Tendency of children's and adults' scientific thinking processes regarding to hypothesis-test procedure). Hacettepe Üniversitesi Ĕ̌itim Fakültesi Dergisi, 36, 340-350.

Zupancic, B., \& Horz, H. (2002). Lecture recording and its use in a traditional university course. SIGCSE Bulletin, 34(3), 24-28.

Corresponding author: Ayse Oguz-Unver, ayseoguz@mu.edu.tr

Australasian Journal of Educational Technology (C) 2013.

Please cite as: Sever, S., Oguz-Unver, A., \& Yurumezoglu, K. (2013). The effective presentation of inquiry-based classroom experiments using teaching strategies that employ video and demonstration methods. Australasian Journal of Educational Technology, 29(3), 450-463. 


\section{Appendix}

The content of the items in the Academic Achievement Test are provided below. All items were provided to participants with check boxes that allowed them to indicate a response of either "true", "false" or "I do not know".

\section{Section I.}

1. Because there is light on Earth in the daytime, there is light in space too.

2. Because the sky is dark during the night, space is dark too.

3. Even if there were no air or particles, light would brighten up the environment by itself.

4. If you wait long enough in a room with no light, the objects in the room will soon begin to appear.

5. The sun and other stars like the sun light up all of space.

\section{Section II.}

6. A shadow can be formed with a single source of light, a screen and an object.

7. The formation of shadows can be explained by the phenomenon of reflection.

8. A half-shadow is formed with at least two sources of light.

9. There's no such thing as a coloured shadow.

10. The primary colours in physics are blue, red and green.

11. The combination of intermediary colors (magenta, cyan, yellow) results in white.

12. The combination of the primary colors results in black.

\section{Section III.}

13. The buoyancy of fluids depends upon the amount of the fluid.

14. The buoyancy of fluids depends on the density of the fluid.

15. The buoyancy of fluids depends on the density of the object.

16. It is impossible to make an object that has sunk down into a fluid float again.

17. The buoyancy of fluids depends on the shape of the object.

\section{Section IV.}

18. Photosynthesis only occurs in green plants.

19. Chlorophyll has an important role in starting off the photosynthesis reaction.

20. Chlorophyll is only contained in the leaves of green plants.

21. Colour pigments such as xanthophyll and carotene cause plants to go through the process of photosynthesis.

22. Plants get all of the nutrients they need for their metabolism directly from their roots and from the earth.

23. Trees that shed their leaves in winter do not go through the process of photosynthesis.

\section{Section $\mathbf{V}$.}

24. Matter in nature exists in solid, liquid or gas form.

25. The density of matter is the same in all its solid, liquid or gas forms.

26. The volume of matter is the same in all its solid, liquid or gas forms.

27. The rising of sea and ocean levels because of global warming can be explained by the melting of the glaciers.

28. The amount of water on the Earth will decrease because of global warming.

\section{Section VI.}

29. An electrical circuit can be made with a battery, wire, light bulb and key.

30. There is no current between the ends of a battery.

31. Static electricity occurs because of the loss of electrical balance when the charge moves from one object to another.

32. An object conducts electricity (conductor) with the movement of positive charges.

33. There is no electricity in neutral objects.

34. When the conducting wires in an electrical circuit changes places with a nonconductor, electrical current will not flow through the circuit.

35. Because the human body is a conductor of electricity, plastic soles should be worn to protect against electrical shock. 